\title{
The Indonesia government strategy to reduce the impact of the Covid-19 pandemic on the national economy
}

\author{
Dani Andrean Widodo ${ }^{1}$ \\ \{dani.andrean@,undiksha.ac.id $\left.{ }^{1}\right\}$ \\ Universitas Pendidikan Ganesha, Indonesia ${ }^{1}$
}

\begin{abstract}
This study aims to determine the fiscal and monetary policy strategies for the stability of the Indonesian economy in dealing with the impact of the Covid 19 virus. In this study, researchers chose to use the descriptive type of research, namely to explain an event whose operations revolve around data collection, data processing and data interpretation. Data is obtained through literature studies, by reading and reviewing and analyzing various literatures, in the form of documents, journals, publication data from ministries and from official websites that release information relevant to research. Meanwhile, data analysis was carried out by reducing, classifying, interpreting and drawing conclusions. The Indonesian government has taken comprehensive fiscal and monetary policies to deal with Covid-19. In the fiscal sector, the Government has implemented a policy of refocusing activities and budget reallocation. From the revenue side, the government must pay attention to the contribution of revenues from PPN and Corporate Income Tax and from the expenditure side, the government must be able to pay attention to the realization of the use of these funds so that they are right on target and prioritize priority activities for preventing the Covid-19 pandemic to reduce the budget deficit.
\end{abstract}

Keywords: Covid-19; Strategy; Government; Economy; Fiscal; Monetary.

\section{Introduction}

Coronavirus is an infectious disease caused by the acute respiratory syndrome coronavirus 2 (Sars-CoV-2). The disease was first discovered in December 2019 in Wuhan, the capital of China's Hubei Province, and has since spread globally, resulting in the 2019-2020 coronavirus pandemic. The World Health Organization (WHO) declared the 2019-2020 coronavirus outbreak an International Public Health Emergency (PHEIC) on 30 January 2020, and a pandemic on 11 March 2020[1]. Covid-19 affects many elements of people's lives and the Indonesia economy. The total positive cases of Covid-19 around the world have reached 31,2 million with a total death of 964 thousand as of 20 September 2020. Each month it has increased to 277,886 on a world scale which illustrates that the struggle for dealing with Covid-19 is still in a tough position in various countries. The escalation has spread in more than 216 countries 
with an additional world daily cases of nearly 300 thousand. Likewise, the epicenter has shifted to large populated countries such as the United States of America, India, Brazil, Russia, South Africa and even Indonesia. Many countries have taken steps ranging from extreme lockdowns to social restrictions and have even implemented what is called The New Normal with health protocols. However, every country has periods where there is an increase in cases again so they continue to make adjustments. For vaccines, development efforts continue to be carried out as an effort to deal with Covid-19, of course with health protocols in various parts of the world. With such conditions, we must see that the risks in the social and financial economy are still very real due to Covid-19 [2].

In Indonesia alone, the cumulative number of positive cases is 248,852 as of 21 September 2020, with the rate of recovery continuing to increase, but if seen from the total deaths, caution must continue to be reduced. Judging from the location, Jakarta Province has again become the largest epicenter center in the number of positive cases. The escalation of the Covid-19 case, such as West Java, Central Java, East Java, South Sulawesi, West Kalimantan and this province are not only large in terms of their population but also large in terms of their contribution to the national economy so that it will definitely affect the performance of the national economy with the conditions of Covid-19 which is still a major factor in influencing the economy, economic growth at both the global and national levels is still largely determined by the ability to control Covid-19 [3].

The crisis due to Covid-19 is currently occurring simultaneously, so that the impact is greatly felt by vulnerable groups who are getting worse, including business groups that need mass crowds, groups of casual daily workers, street vendors, workers affected by layoffs, farmers, the poor, and so on [4]. In this situation, it is understandable that the government does not dare to take lockdown steps in this phenomenon, because the risk leads to an economic disaster, which automatically has implications for other social impacts [2]. The simple picture is that the cycle of economic activity in the community has drastically decreased, so the government must take strategic policies that are accelerated in dealing with the economic difficulties that befall the community [5]. If the government is slow in making strategic decisions, then the vulnerability to social disasters, including conflicts, will easily occur [4].

The government responds to the impact of Covid-19 by issuing Government Regulation in lieu of Law No.1 of 2020 concerning State Financial Policy and Financial System Stability for Handling the Pandemic Corona Virus Disease 2019 (Covid-19) and / or in the Context of Facing a Dangerous Threat The National Economy and / or Financial System Stability of the Perppu is then promulgated into Law Number 2 of 2020 [6].

The Government Regulation in lieu of Law above also provides additional authority to Bank Indonesia, the Deposit Insurance Corporation, and the Financial Services Authority. The Financial System Stability Committee is given the authority to handle financial system stability, including providing short-term liquidity loans to systemic and non-systemic banks. In addition, BI was given the authority to purchase long-term government bonds or state securities in the primary market. Corporations are also given the opportunity to obtain funding through the resale of debt securities.

Initially, the government allocated a total of IDR 405.1 trillion for handling Covid-19 in the health sector and national economic recovery. Furthermore, the government summarizes various policies in dealing with the impact of Covid-19 in a program called National Economic Recovery (PEN). The government has allocated APBN funds for economic recovery amounting to IDR 695.2 trillion [6].

Various regulations, both laws and others, have been made by the government as a legal basis in an effort to increase national economic growth. The formulation of the problem in 
the subject matter of this paper, namely what fiscal policies are taken by the government in maintaining national economic stability and what steps are taken by BI to maintain the stability of the national financial system.

The purpose of discussing the problems in this paper is so that readers can know and understand the various strategies taken by the Indonesian government in suppressing the impact of the Covid-19 pandemic on national economic stability, such as fiscal policies made by the Ministry of Finance and monetary policies adopted by Bank Indonesia. It is hoped that overcoming the problems arising from Covid-19 will not put too much pressure on the APBN deficit. Therefore, a strategy is needed that can help regulate the current economy. Fiscal policy in terms of government revenue and expenditure has played a very large role in overcoming the impact of Covid-19.

\section{Method}

This research uses a descriptive qualitative approach, which is an understanding that understands the various concepts found in the research process, using content analysis techniques and library research. The content analysis technique is a research method used to see the conclusions of a text. Or in other words, content analysis is a research method that seeks to reveal the manifested and latent ideas of the author. Meanwhile, library research in this study uses types and sources of secondary data obtained from research, articles and reference books that discuss topics related to the research theme [7].

In the data collection process, researchers conducted a document study process by collecting various articles from government websites such as www.covid.go.id, information from online news such as www.kompas.com, and other sources of information. Other sources that are no less important are various scientific articles published in various national and international journals. The various sources that have been collected are then carried out a comparative study and analysis, so that the appropriate source is determined according to the theme of the writing being made.

The final stage of this research process is the writing process by describing the data that has been collected so that the economic impact of Covid-19 on Indonesian society can be seen in detail.

\section{Result and Discussion}

Realization of tax revenue until the end of May 2020 was recorded to have decreased by $10.8 \%$ compared to the same period last year. The decline was recorded to be deeper than the $3.1 \%$ end of April. This was explained by the Minister of Finance Sri Mulyani Indrawati, S.E., M.Sc. Ph.D. through the APBN video conference, that the tax revenue realization until the end of May 2020 was valued at IDR 444.56 trillion or $35.4 \%$ of the 2020 APBN target which has been amended according to Presidential Decree No. 54/2020 worth IDR 1,254.1 trillion.

Table 1. Realization of tax revenue

\begin{tabular}{|c|c|c|c|}
\hline Uraian & $\begin{array}{l}\text { APBN } \\
2020^{*}\end{array}$ & $\begin{array}{c}\text { Jan- } \\
\text { Mel } \\
2020 \\
(\mathrm{Rp})\end{array}$ & $\begin{array}{c}\Delta \% \\
19-20\end{array}$ \\
\hline Pajak Penghasilan (PPh) & 703,34 & 281,81 & $-12,44$ \\
\hline - Non-Migas & 659,6 & 264,83 & $-10,38$ \\
\hline - Migas & 43,75 & 16,98 & $-35,58$ \\
\hline PPN \& PPnBM & 529,65 & 159,99 & $-7,95$ \\
\hline PBB dan Pajak Lainnya & 21,11 & 2,76 & $-3,45$ \\
\hline Jumlah & $1.254,11$ & 444,56 & $-10,82$ \\
\hline
\end{tabular}


The Minister of Finance issued Regulation of the Minister of Finance Number 23 of 2020 (PMK 23 of 2020) Regarding Tax Incentives for Taxpayers Affected by the Covid-19 Virus Outbreak. The provision of this incentive is a response from the government to the decline in productivity of business actors due to the economic decline of taxpayers due to this outbreak $[8]$.

\section{Income Tax $(\mathrm{PPh})$ Article 21}

This incentive will affect the income that each employee will receive for the past 6 months. If previously employees were deducted from Article 21 of their income, from April to September 2020 the employee will receive another Income Tax 21 discount. The deduction is given along with the monthly income received by the employee. The status, which was previously borne by the recipient of the income, becomes borne by the government or it is called Government-borne Tax (PDP). So, if an employer violates the regulations related to this PMK, they will be subject to sanctions in accordance with the applicable regulations [8].

\section{Income Tax Article 22 Import}

Income Tax Article 22 Imports are given incentives in the form of tax payment exemption. This exemption is the effect of the reduced activity of sending goods to enter Indonesia in order to prevent the spread of the virus which is increasingly developing in Indonesia, whether it is a temporary suspension of the country of origin or a reduction in spending activities of importers in Indonesia. The decline in import activity has greatly affected Indonesia's trade balance, so it is necessary to provide a stimulant through incentives so that taxpayers who are business actors will be enthusiastic about carrying out activities in such a non-conducive situation. Taxpayers who carry out import activities will be given an exemption from import income tax article 22 for 6 months. The granting of this facility is given through an Import Tax Free Certificate (SKB) to the taxpayer [8].

Installments of Income Tax Article 25

Income Tax Article 25 which will receive incentives with a reduction in the amount of installments by $30 \%$ of the total installments that should be paid over the next 6 months. Income Tax Article 25 is included in this regulation because many business actors have started to reduce their activities or even temporarily stop their business as long as this outbreak has not stopped. When conditions like this the productivity of the taxpayer it would be unfair if taxpayers who had been paying installments of this type of tax were not given incentives. During this regulation, taxpayers do not need to apply for reduced installments to get incentives because it will take effect automatically [8].

\section{Value Added Tax (VAT) Restitution}

VAT is given incentives during the Covid-19 outbreak. For VAT, the treatment of incentives is different from the three previous types of taxes. The VAT incentive provided is by facilitating the process of providing restitution to PKP which has been determined in PMK 23 of 2020 for the next 6 months starting in April. There are differences in the nominal limit of restitution given to PKP Exporters and PKP Non Exporters. For PKP that acts as an exporter there is no nominal limit on the VAT that will be refunded, while for PKP Non-Exporters, an accelerated restitution is given with a maximum value of 5 billion rupiah. Exporter PKP will get unlimited facilities in this time to apply for restitution. This is adjusted to the application of VAT rates that have been provided by exporters. For PKP who are classified as tax incentives, 
there is no need to submit applications for low-risk PKP determination to registered Tax Offices $[8]$.

In increasing state revenue, the government will implement digital taxes or Trade Through Electronic Systems (PMSE). Perppu No.1 / 2020 states that the PMSE scheme will collect digital taxes in the form of value added tax (VAT) and $\mathrm{PPh}$. If the regulation is immediately enacted, the tax authorities will immediately make regulations so that the digital tax law umbrella becomes more specific. The tax authorities and the Ministry of Finance are preparing a Minister of Finance regulation (PMK) as the legal basis for VAT in the PMSE. Meanwhile, $\mathrm{PPh}$ and taxes on digital transactions will be prepared by a Government Regulation (PP). This activity is very relevant to be carried out in relation to the increasing online activities carried out by economic actors as a result of social distancing and PSBB. Activities using the zoom application increase during this pandemic period, so that activities can be levied on the activity tax. Online trading for which data is not currently accessible to tax collectors can be subject to strict supervision and regulations to comply with the merchant's obligations as taxpayers who carry out their activities through electronic media[3].

During the Covid 19 pandemic, the government adopted policies namely: support for the health sector, medical energy monthly incentives, social protection, electricity rates, raising the pre-work card budget, economic recovery, anticipating the APBN deficit, KUR customers getting installment relief, in the non-fiscal sector, refocusing and relocation of expenditures, prepare a Perpu. Furthermore, the Ministry of Finance will reallocate APBN funds amounting to IDR 62.3 trillion [9].

The funds are taken from official travel budgets, non-operational spending, honoraria, for handling / controlling Covid-19, social protection (social safety net) and incentives for the business world. It is also hoped that the APBD will be refocused and reallocated for these 3 things. Strengthening the handling of Covid-19, is carried out by providing facilities and medical devices, medicines, incentives for the medical team to handle Covid-19 patients and other needs. Social safety net is given to increase people's purchasing power through the family hope program $(\mathrm{PKH})$, Smart Indonesia Card (KIP), food cards and prosperous rice. The government is projecting an increase in budget financing to IDR. 852.9 Trillion due to the impact of the Covid-19 pandemic This figure has increased by IDR. 547 trillion from the 2020 Revenue and Expenditure Budget (APBN). The APBN deficit widened 5.07\% of GDP. Investment financing also increased. From minus 74.2 trillion to minus 229.3 trillion[10].

Based on materials from the Ministry of Finance, this year's budget financing increased by IDR. 186.3 trillion from Presidential Regulation (Perpres) No. 54 of 2020 which amounted to Rp. 852.9 trillion to Rp. 1,039.2 trillion. This is in accordance with the amount of the 2020 State Budget deficit outlook. Debt financing was recorded to have increased by IDR. 213.9 trillion from IDR. 1,006.4 trillion to IDR. 1,220.3 trillion. This debt financing outlook increases, to finance a widening budget deficit and additional investment financing. Investment financing was recorded to have increased by IDR. 24.6 trillion from IDR. 229.3 trillion to IDR. 253.9 trillion. This includes additional SOE investment financing which is part of the funding for the national economic recovery program[8].

Overcoming the economic impact of the Covid-19 outbreak on the Indonesian economy will largely be determined by policy choices and the government's preparedness to deal with the outbreak. The difference in the level of fatality rates in various countries is also a valuable lesson that government policies are very decisive in overcoming this pandemic, in addition to system support and community behavior. Some steps should be taken by the government for efficiency in the production side [9]: issuance of debt securities (sun) in rupiah 
figures to reduce interest payments; refocusing the 2020 state budget; the legal consequences for misappropriation of the covid-19 countermeasures fund.

Due to the outbreak of the Covid-19 pandemic, Bank Indonesia (BI) continues to strengthen all instruments and policies to stabilize the rupiah exchange rate, control inflation. and support financial system stability. At the same time, BI is also active in preventing a decline in the economic activity of Isbih Langit through close coordination with the Government and the Financial System Stability Committee (KSSK).

The BI policy mix consists of six important aspects. First, the cut in the monetary policy rate (BI7DRR) four times until July 2020, each by 25 bps. This reduction in policy interest rates is consistent with the forecast for low and controlled inflation in the $3+1$ percent target range, as well as to support national economic recovery [11].

Second, BI also stabilized and strengthened the rupiah by increasing the intensity of intervention policies both on the spot market. Domestic Non Deliverable Forward (DNDF), as well as purchases of Government Securities and the secondary market Rupiah stabilization was also pursued through a reduction in the mandatory minimum reserve (GWM) of foreign currencies, a decrease in the rupiah reserve requirement for many who carry out export-import activities, financing micro small and medium enterprises and other priority sectors, as well as expanding the types of ringing of transactions for foreign investors.

Third, BI continues to expand instruments and transactions in the money market and foreign exchange market. This is taken. On the other hand, it can provide many trading assets, ternate hedging, value-for-money rupiah exchange through DNDF transactions, multiplying foreign exchange swap transactions, providing repo terms for banking needs. as well as strengthening monster operations and in the real financial market through various instruments, BI also strengthens the term deposit instrument eyebrows to improve liquidity management, foreign exchange in the domestic market and encourages banks to use the reduction in foreign currency reserve requirement reserves that have been decided by BI.

Fourth, to encourage financing for the business world and national economic recovery, $\mathrm{BI}$ injected liquidity (quantitative easing) into the money market and banks in large quantities Until July 14, 2020, BI has injected liquidity of around IDR. 633.24 trillion, among others, through the purchase of Government Securities from the secondary market, provision of banking liquidity with $\mathrm{SBN}$ repos, foreign exchange swaps and reduction in the rupiah statutory reserve requirement (GWM).

Fifth, easing macroprudential policies to encourage banks to finance the business and financial world. This is done through loosening the provisions of the Loan to Value Ratio (LTV), Macroprudential Intermediation (RIM), as well as a decrease in the rupiah reserve requirement for financing the business world, especially for export-import and for micro small and medium enterprises in order to mitigate the impact of Covid-19. In addition, efforts will also be made to provide liquidity for banks in restructuring loans for micro small and medium enterprises and ultra-micro businesses that already have loans from financial institutions[12].

Sixth, Keep the ease and smooth operation of the cash and non-cash payment system to support various economic and financial transactions This is done through hygienic circulation of money, as well as encouragement for the public to use more cash transactions, such as electronic money, internet banking, and the use of Indonesian QR Code. BI is also accelerating the implementation of the digital economy and finance as part of efforts to recover the economy through collaboration between banks and fintech.

In addition, non-cash payments are also intended to support government programs in channeling social assistance funds, such as the family hope program (PKH) and non-cash food assistance, the pre-employment card program, and the Indonesia smart-college card program[6]. 


\section{Conclusion}

The Indonesian government takes a policy comprehensive in the field of fiscal and monetary for facing Covid-19. In the fiscal sector, the Government carry out activity refocusing and budget reallocation policies. From the revenue side, the government must pay attention to the contribution of revenue from VAT and Corporate Income Tax and from the expenditure side, the government must be able to pay attention to the realization use of these funds to be right on target and prioritize pandemic prevention priority activities Covid-19 To reduce the budget deficit. Fiscal policy strategies that affect output and inflation in the Indonesian economy can be seen from the stated government policy in 3 stimuli. Government payments can refocus / revise the budget in the APBN to optimize its use during the Covid-19 pandemic. Besides, with new normal policy recently, hopefully can support this economic growth. With operation of the industrial sector, the economy can wriggle back and pick up growth the economy Due to the outbreak of the Covid-19 pandemic, Bank Indonesia (BI) continues to strengthen all instruments and policies to stabilize the rupiah exchange rate, control inflation. and support financial system stability. At the same time, BI is also active in preventing a decline in the economic activity of Isbih Langit through close coordination with the Government and the Financial System Stability Committee (KSSK). The BI policy mix consists of six important aspects.

\section{References}

[1] E. Supriatna, "Wabah corona virus disease (covid 19) dalam pandangan islam," Salam J. Sos. dan Budaya Syar-i, 2020, doi: 10.15408/sjsbs.v7i6.15247.

[2] O. Abodunrin, G. Oloye, dan B. Adesola, "Coronavirus Pandemic and Its Implication on Global Economy,” Int. J. Arts, Lang. Bus. Stud., 2020.

[3] H. Hidayatullah dan N. Nasrullah, "Enforcement of health law in the crisis period of pandemic outbreak covid-19: 'The policy of Large Scale Social Limitation (LSSL) in Indonesia Viewed of the Theory of Al-Maqaashid Asy-Syar'iyyah,"” Syariah J. Huk. dan Pemikir., vol. 20, no. 1, hal. 41, Jul 2020, doi: 10.18592/sjhp.v20i1.3633.

[4] H. H. Kurniawan, A. M. Salahuddin, Muslim, dan N. Sri, "Konsep kebijakan strategis dalam menangani eksternalitas ekonomi dari covid - 19 pada masyarakat rentan di indonesia Heri," Indones. J. Soc. Sci. Humanit., 2020.

[5] O. Evans, "Socio-economic impacts of novel coronavirus: The policy solutions," BizEcons Q., 2020.

[6] I. W. P. Yasa, “Tri Hita Karana untuk Pencegahan COVID-19 di Bali,” J. Socius J. Sociol. Res. Educ., 2020, doi: 10.24036/scs.v7i1.176.

[7] Azwar Iskandar dan Khaerul Aqbar, "Kedudukan Ilmu Ekonomi Islam di Antara Ilmu Ekonomi dan Fikih Muamalah: Analisis Problematika Epistemologis," Nukhbatul 'Ulum J. Bid. Kaji. Islam, 2019, doi: 10.36701/nukhbah.v5i2.77.

[8] D. E. Silalahi dan R. R. Ginting, "Strategi Kebijakan Fiskal Pemerintah Indonesia dalam Menghadapi Dampak Pandemi COVID-19,” Jesya (Jurnal Ekon. Ekon. Syariah), 2020.

[9] A. Feranika dan D. Haryati, "Strategi Kebijakan Fiskal Terhadap Output dan Inflasi pada Perekonomian Indonesia dalam Menghadapi Dampak Virus Covid 19," Bus. Innov. Entrep. J., 2020, doi: 10.35899/biej.v2i3.154.

[10] L. Tri Putri Nurhidayat, "Pengaruh Covid-19 Terhadap Pertumbuhan UMKM di Indonesia," sukabumiupdate.com, 2020. . 
[11] Yenti Sumarni, "Pandemi Covid-19: Tantangan Ekonomi Dan Bisnis," J. Ekon. dan Perbank. Syariah, 2020.

[12] S. Stanciu, R.-I. Radu, V. Sapira, B.-D. Bratoveanu, dan A.-M. Florea, "Consumer Behavior in Crisis Situations. Research on the Effects of COVID-19 in Romania," Ann. Dunarea Jos Univ. Galati. Fascicle I. Econ. Appl. Informatics, vol. 26, no. 1, hal. 5-13, Mei 2020, doi: 10.35219/eai1584040975. 